ПРОФЕСІЙНА ПІДГОТОВКА ФАХІВЦІВ ЗА ДУАЛЬНОЮ ФОРМОЮ ЗДОБУТТЯ ОСВІТИ

\title{
PROFESSIONAL TRAINING OF SPECIALISTS UNDER THE CONDITIONS OF DUAL FORM OF EDUCATION
}

У статті розкрито особливості професійної підготовки фрахівців за дуальною фрормою здобуття освіти. Розкрито сутність дуальної освіти, яка передбачає узгоджену взаємодію освітньої та виробничої ссрери з підготовки кваліфрікованих кадрів певного профрілю в рамках організаційно-відмінних форм навчання. Указано, що дуальна освіта передбачає усунення основних недоліків традичійних форм і методів навчання майбутніх кваліфікованих робітників, подолання розриву між теорією та практикою, освітою та виробничтвом, спрямована на підвищення якості підготовки квалісрікованих кадрів у рамках нових організаційно-відмінних форм навчання. Виокремлено, що заклад освіти повинен забезпечити теоретичну підготовку, чілісність освітньої програми, відповідність стандартам освіти, відповідальність за якість підготовки здобувачів освіти; спільно з роботодавцем визначати освітні програми, за якими організовується освітній процес за дуальною фоормою здобуття освіти. Акцентовано на використанні елементів дуального навчання в закладах вищої освіти, на налагоджені співпраці з роботодавцями, на вимогах до здобувачів освіти на робочих місцях галузі «Освіта / Педагогіка». Зокрема, здобувач освіти повинен виконувати навчальний план згідно 3 графіком навчального прочесу, дотримуватися правил внутрішнього трудового розпорядку підприємства, дотримуватися правил охорони праці, нести матеріальну відповідальність за обладнання та майно, своєчасно виконувати завдання, покладені на нього під час навчання на робочому місці. Наведено приклади впровадження елементів дуального навчання в Хмельницькій гуманітарно-педагогічній академії, зокрема зі спеціальностей «Дошкільна освіта», «Початкова освіта», «Музичне мистецтво», «Хореографрія» та інших. Початкова освіта - че часткове працевлаштування в закладах загальної середньої освіти на посаді вчителя початкових класів, педагога-оранізатора або вихователя групи продовженого дня, на посаді керівників дитячих хореографіч них колективів, на посаді вихователя, асистента вихователя, інструктора з фрізичної культури. Таким чином, дуальна фрорма здобуття освіти є актуальною та продиктована бажанням здобувачів реалізовувати себе в тій сорері, для якої вони навчаються, але вона матиме не масовий характер, а виключно індивідуальний. У такому контексті заклад вищої освіти також може використовувати й неформальну освіту - перезарахувавши таким здобувачам програмн результати навчання, отримані під час проходження практик.
Ключові слова: професійна підготовка, дуальна форма здобуття освіти, вища освіта, Хмельницька гуманітарно-педагогічна академія.

The article reveals the peculiarities of professional training of specialists under the conditions of dual form of education. The essence of dual education is revealed, which provides for coordinated interaction of the educational and the industria spheres for the training of qualified personnel of a certain profile within the framework of organizationally different forms of education. It is stated that the dual education involves eliminating the main shortcomings of traditional forms and methods of training the future skilled workers, bridging the gap between theory and practice, education and production, aimed at improving the quality of training of specialists in new organizational-different forms of training. It is emphasized that the educational institution should provide theoretical training, the integrity of the educational program, compliance with educational standards, responsibility for the quality of training of students; together with the employer to determine the educational programs according to which the educational process is organized under the conditions of the dual form of education. Emphasis is placed on the use of elements of dual education in higher education institutions, on establishing cooperation with employers, on the requirements for applicants of education in the workplace of the sphere "Education / Pedagogy". In particular, the student should follow the curriculum in accordance with the schedule of the educational process, follow the rules of internal labor regulations of the enterprise, follow the rules of labor protection, be responsible for equipment and property, timely perform tasks assigned to him or her during on-the-job training. Examples of the introduction of elements of dual education in Khmelnytskyi Humanitarian-Pedagogical Academy are offered, in particular in the specialties "Pre-School Education", "Primary Education", "Music Art", "Choreography" and others. Primary education means partial employment in general secondary education institutions as a primary school teacher, teacher-organizer or educator of the extended day group, as a leader of children's choreographic groups, as an educator, assistant educator, physical education instructor. Thus, the dual form of education is relevant and dictated by the desire of students to realize themselves in the sphere for which they study, but it will not be mass, but only individual. In this context, a higher education institution can also use nonformal education - by re-enrolling the program learning outcomes obtained during internships. Key words: professional training, dual form of education, higher education, Khmelnytskyi Humanitarian-Pedagogical Academy.
Хмельницької гуманітарно-педагогічної академії
Постановка проблеми в загальному вигляді. Трансформаційні процеси, пов'язані з європейською інтеграцією, позитивні результати ресрорм, підвищення конкурентоспроможності економіки передбачають створення відповідної національ- ної системи освіти та підготовки кадрів. Важливим $€$ створення умов для поєднання роботи з навчанням як у фрорматі здобуття освіти за вечірньою або заочною фрормою навчання, так і у фрорматі практичної підготовки здобувачів вищої освіти 
денної фрорми навчання та здобувачів профресійної (професійно-технічної) освіти на робочих місцях. У Законі України «Про освіту» передбачено, що особа має право здобути освіту в різних фрормах або поєднуючи їх, та визначено такі основні форми здобуття освіти: інституційна (очна (денна, вечірня), заочна, дистанційна, мережева); індивідуальна (екстернатна, сімейна (домашня), педагогічний патронаж, на робочому місці (на виробництві); дуальна [1].

Аналіз останніх досліджень і публікацій. Питання впровадження дуальної освіти розкриваються в працях багатьох вітчизняних і зарубіжних авторів, зокрема: Н. Абашкіної, І. Акімової, У. Бека, Х. Беннера, І. Бойчевської, В. Землянського, Я. Канакіна, В. Кларіна, В. Грайнерта, Г. Грунера, А. Келя, Г. Кершенштайнера, Є. Терещенкова й інші. Проблеми дуального навчання як інтерактивної організації освітнього процесу розкриваються в наукових працях С. Дражниці; основні ознаки дуальної моделі навчання досліджено в публікаціях Л. Сидакової та інших. [2].

Формулювання цілей статті. Мета статті-розкрити особливості профресійної підготовки фрахівців за дуальною фрормою освіти, її зміст, специфіку, технології.

Виклад основного матеріалу. Термін «дуальна система» (від лат. dualis - подвійний) був введений у педагогічну термінологію в середині 60-х років минулого століття у ФРН - як нова, більш гнучка фрорма організації професійного навчання. Дуальність як методологічна характеристика професійної освіти передбачає узгоджену взаємодію освітньої та виробничої сорери з підготовки кваліфікованих кадрів певного профрілю в рамках організаційно-відмінних форм навчання.

За Законом України «Про вищу освіту», дуальна фрорма здобуття вищої освіти - це спосіб здобуття освіти здобувачами денної фрорми, що передбачає навчання на робочому місці на підприємствах, в установах та організаціях для набуття певної кваліфікації обсягом від 25 відсотків до 60 відсотків загального обсягу освітньої програми на основі договору. Навчання на робочому місці передбачає виконання посадових обов'язків відповідно до трудового договору. Дуальна освіта передбачає усунення основних недоліків традиційних фрорм і методів навчання майбутніх квалісрікованих робітників, подолання розриву між теорією і практикою, освітою й виробництвом, спрямована на підвищення якості підготовки кваліфікованих кадрів у рамках нових організаційновідмінних фрорм навчання [3].

Дуальна освіта, є пріоритетною для професійно-технічної сорери. У зв'язку 3 динамічними потребами ринку праці, швидкими темпами розвитку суспільства, а також необхідності налагодження співпраці у системі «здобувач освітнього рівня освіти - заклад освіти - підприємство - держава». Саме у такій взаємодії може бути ефективною така система освіти.

Дуальну освіту, або її елементи, у системі підготовки кваліфікованих кадрів варто апробувати у сорері професійно-технічної освіти, а також вищої.

У цьому контексті заклад освіти повинен забезпечити теоретичну підготовку, цілісність освітньої програми, відповідність стандартам освіти відповідальність за якість підготовки здобувачів освіти; спільно 3 роботодавцем визначати освітні програми, за якими організовується освітній процес за дуальною формою здобуття освіти. Заклад освіти відповідає за налагодження співпраці 3 роботодавцями за відбір підприємств, установ та організацій, що надають місця практичної підготовки за дуальною фрормою здобуття освіти.

Також спільно 3 роботодавцями розробляє i затверджує навчальний план відповідної освітньої програми; забезпечує узгодження змісту теоретичної та практичної частини, координує навчання здобувача освіти на підприємстві, приймає звіт про результати навчання за дуальною формою та оцінює результати;

Важливе значення має обговорення освітньої програми за дуальною фформою здобуття освіти щодо відповідності професійним стандартам та вимогам роботодавців до компетентностей майбутніх фрахівців.

Згідно з Концепцією підготовки здобувачів за дуальною формою освіти роботодавець може ініціювати налагодження співпраці із закладом освіти щодо підготовки, в тому числі шляхом ініціювання створення програм дуального навчання; брати участь у розробленні та затвердженні освітніх програм та навчального плану, а також у відборі здобувачів освіти на навчання за дуальною формою здобуття освіти.

Роботодавець надає робоче місце здобувачу освіти на підприємстві, в установі чи організації, що передбачає грошову винагороду, а також надає необхідні ресурси та інформаційні матеріали для виконання роботи та навчального плану.

На підприємстві спільно з профспілками вирішують питання умов праці, запровадження та визначення розмірів надбавок, доплат, винагород для працівників, що здійснюють навчання здобувачів освіти на виробництві.

Згідно із законодавчими документами здобувач освіти повинен відповідально ставитися до виконання навчального плану згідно з графіком навчального процесу відповідно до цілей та завдань навчання на робочому місці; дотримуватися правил внутрішнього трудового розпорядку підприємства, установи чи організації. Також він повинен підтримувати контакт 3 особою, відповідальною за виконання освітньої програми дуальної фрорми здобуття освіти, дотримуватися правил 
охорони праці, виробничої санітарії, гігієни праці протипожежної охорони, нести матеріальну відповідальність за обладнання та майно відповідно до укладеного договору [5].

Здобувач освіти повинен своєчасно на належному рівні виконувати завдання, покладені на нього під час навчання на робочому місці, та індивідуальні завдання згідно з навчальним планом.

Однак все вищезазначене приведе до змін у навчально-виробничому процесі. Це зміна співвідношення навчального часу: теоретичне навчання - 30\%, виробниче навчання та виробнича практика - 70\% навчальних годин; упровадження блочно-модульної побудови навчального процесу: опанування базового модуля на базі закладу освіти, а потім чергування: модуль теорії (1-2 тижні) на базі закладу освіти / модуль практики на базі підприємств, установ, організацій; оцінювання результатів навчання - відповідно до реальних показників професійної підготовки, підтвердженої в умовах виробництва.

У вищій освіті дуальна система може бути запроваджена у підготовці фрахівців мистецької, технічної та IT галузях, в інших - можливе використання лише елементів. Це може відбутися шляхом чергування 2 тижні теоретичного навчання/4 тижні практичної підготовки у складі мистецьких колективів. Можливий інший варіант графріка освітнього процесу: протягом трьох років здобувач отримує академічну підготовку в закладі вищої освіти, а останній рік він працює у колективі. Періодично, здобувач може відвідувати 3 ВО для підтвердження результатів навчання. У процесі підготовки здобувачів вищої освіти у галузі Освіта/Педагогіка можна використати деякі елементи дуальної освіти [4].

Адже на старших курсах майбутні фрахівці вдало поєднують навчання і працю, переводячись на індивідуальний графрік.

Хмельницька гуманітарно-педагогічна академія з 2018 навчального року розпочала підготовку до реалізації Концепції підготовки фрахівців за дуальною формою здобуття освіти. За період 2018-2020 рр. здійснено підготовчу роботу.

А саме: опрацьована наявна нормативно-правова база; проведено консультації 3 роботодавцями щодо можливостей реалізації Концепції; налагоджено постійні зустрічі роботодавців і їх потенційних працівників, нині - студентів, у рамках проєкту «Центр кар'єри ХГПА» (тренінги, дискурси, панельні дискусії, рекламні акції тощо); розглядаються варіанти змін до змісту освіти та графіка навчально-виробничого процесу відповідно до запитів роботодавців 3 урахуванням вимог державних стандартів 3 професій, які продукуються в навчальному закладі, на основі компетентнісного підходу та блочно-модульної побудови навчального процесу в умовах дуальної освіти. Також вивчаються можливості співпраці із роботодавцями з метою визначення кластерів дуальної освіти для ХГПА - закладів освіти, культури, туристичної й соціальної сфрери у відповідності до переліку професій, які продукує ХГПА для упровадження дуальної форми навчання; активно проводиться робота над впровадженням спільного проєкту «Територіальна громада - ХГПА: наукова, освітньо-методична й соціально-культурна співпраця».

Для цього у положенні заклад вищої освіти має передбачити підставу (у зв'язку, з працевлаштуванням за спеціальністю).

У Хмельницькій гуманітарно-педагогічній академії впроваджують елементи дуального навчання, коли певну частину часу здобувачі вищої освіти отримують знання в аудиторіях, а частину - на місцях майбутньої профресійної діяльності.

Наприклад, здобувачі вищої освіти спеціальності «Початкова освіта» поєднують навчання в Хмельницькій гуманітарно-педагогічній академії на спеціальності «Початкова освіта» 3 частковим працевлаштуванням у закладах загальної середньої освіти на посаді вчителя початкових класів, педагога-організатора або вихователя групи продовженого дня.

Здобувачі вищої освіти спеціальності «Хореографрія» поєднують навчання з відкриттям власних гуртків та частковим працевлаштуванням на посаді керівників дитячих хореографічних колективів.

Здобувачі вищої освіти спеціальності «Дошкільна освіта» поєднують навчання 3 частковим працевлаштуванням у закладах дошкільної освіти на посадах вихователя, асистента вихователя, інструктора з фрізичної культури.

Здобувачі вищої освіти спеціальностей «Середня освіта (Українська мова та література)», «Середня освіта (Іноземна мова та зарубіжна література (англійська))» поєднують навчання з частковим працевлаштуванням у закладах загальної середньої освіти на посадах вчителя української мови та літератури, вчителя англійської мови, вчителя зарубіжної літератури, в бюро перекладів.

В такому випадку здобувачі вищої освіти оформляють індивідуальний навчальний графік, додають довідку про працевлаштування.

Здобувачам вищої освіти зараховується проходження різних видів навчальної та виробничої практик та змістові модулі окремих дисциплін.

Переважна кількість студентів спеціальностей 024 Хореографія, 025 Музичне мистецтво, 014 Середня освіта (Музичне мистецтво) та 014 Середня освіта (Образотворче мистецтво), 242 Туризм першого (бакалаврського) та другого (магістерського) рівня вищої освіти Хмельницької гуманітарно-педагогічної академії знаходять своє перше місце роботи ще під час навчання у закладі. Зокрема, вони мають можливість працю- 
вати у закладах дошкільної, загальної середньої, позашкільної, початкової мистецької освіти, закладах культури та мистецтва, приватних колективах, клубах та студіях, театрах танцю.

Кафедри і заклад вищої освіти йдуть назустріч студентам, надають різноманітну методичну та фахову допомогу, сприяють працевлаштуванню студентів, які мають намір набувати практичного досвіду безпосередньо під час виконання професійних задач в реальних мистецьких колективах. Відтак, кількість студентів, які після закінчення закладу продовжують працювати за фрахом підтверджує правильний напрям практичної мотивації і роботи із студентами ще під час їхнього навчання.

Висновки. Таким чином, дуальна фрорма здобуття освіти $є$ актуальною та продиктована бажанням здобувачів реалізовувати себе у тій сфері, для якої вони навчаються, але вона матиме не масовий характер, а виключно індивідуальний. У такому контексті заклад вищої освіти, також може використовувати й неформальну освіту - перезарахувавши таким здобувачам програмні результати навчання, отримані під час проходження практик.

Перспективи подальших розвідок у такому напрямі. Перспективи подальших розвідок щодо профресійної підготовки фрахівців за дуальною фрормою здобуття освіти ми вбачаємо в розробці моделі такої підготовки, умов її реалізації тощо.

\section{БІБЛІОГРАФІЧНИЙ СПИСОК:}

1. Вчитися на роботі: як працюватиме дуальна освіта в Україні. Український інтерес : вебсайт. 19 вересня 2018 p. URL: https://uain.press/science/ education/vchytysya-na-robotiyak-zapratsyuye-dualnaosvita-v-ukrayini-943921 (дата звернення: 21.04.2021).

2. Дражниця С.А., Дражниця О.М. Дуальне навчання як інтерактивна фрорма організації навчального процесу. Збірник наукових праць Хмельницького інституту соціальних технологій Університету «Україна». 2016. № 12. С. 17-20.

3. Про вищу освіту : Закон України від 01 липня 2014 р. № 1556-VII / Верховна Рада України. URL: https://zakon.rada.gov.ua/laws/show/1556-18\#Text (дата звернення: 22.04.2021).

4. Про освіту : Закон України від 30 березня 2021 р. № 1369-IX / Верховна Рада України. URL: https://zakon.rada.gov.ua/laws/show/2145-19\#Text (дата звернення: 22.04.2021).

5. Про схвалення Концепції підготовки фрахівців за дуальною фрормою здобуття освіти : Розпорядження Кабінету Міністрів України від 19 вересня 2018 р. № 660-р / Кабінет Міністрів України. URL: https://zakon.rada.gov.ua/laws/show/660-2018-p\#Text (дата звернення: 22.04.2021). 